\title{
COMPARATIVE ANALYSIS OF ULTRASOUND GUIDED CENTRAL VENOUS CATHETERIZATION COMPARED TO BLIND CATHETERIZATION
}

\author{
Darko Sazdov ${ }^{1}$, Marija Jovanovski Srceva² ${ }^{2}$ Zorka Nikolova Todorova ${ }^{3}$ \\ ${ }^{1}$ Clinical Hospital Acibadem-Sistina, Skopje, Department for Intensive Care \\ ${ }^{2}$ University Clinic for Traumatology, Orthopedics, Anesthesia, Reanimation and Intensive Care, Skopje \\ ${ }^{3}$ European Eye Hospital, Skopje
}

Corresponding author: Darko Sazdov, mail:dr.sazdov@gmail.com

\section{ABSTRACT}

\section{Introduction:}

Central venous catheterization is performed by the landmark method and ultrasound guided method. The purpose of the study was to compare the success, average number of attempts, average time to return of blood, and complication rate between the two methods.

\section{Material and Methods:}

This was a prospective study done in the Intensive Care Unit of the Acibadem Sistina Clinical Hospital, in Skopje. There were 400 patients in need of central venous catheter and they were prospectively randomized in two groups. The patients randomized in the examined-ultrasound group underwent real-time ultrasound-guided catheterization and the patients randomized in the control-landmark group were catheterized using the landmark method. Internal Jugular, Subclavian and Femoral vein were catheterized in both groups. The Overall success, success on the first attempt, time to the return of blood, number of attempts and complications at the moment of catheterization such as arterial puncture, pneumothorax and hematoma formation were the main outcome measures. Results:

The catheterization using the landmark method was successful in $90.5 \%$ of patients, $60.5 \%$ of which during the first attempt. The cannulation using real-time ultrasound guidance was successful in $98 \%$ of patients with a first pass success of $77 \%$. The complication rate with the landmark method was $14.5 \%$ versus $4 \%$ with real-time ultrasound guidance $p<0.05(p=0.0008)$.

\section{Conclusion:}

Real-time ultrasound guidance improves success, decreases number of attempts, decreases average time to the return of blood and reduces mechanical complications rate.

Key words: Landmark, ultrasound, central venous cauterization

\section{INTRODUCTION}

Central venous catheters (CVC) are reserved for patients in the intensive care unit, in the operating theatre, at medical or surgical wards, in elective or urgent procedures [1], as a part of everyday medical practice $[2,3]$. In the United States, over 5 million central venous catheters are placed every year [4].
For CVC placement usually internal jugular vein (on the neck) [5], subclavian vein (under the clavicle) [6] and femoral vein (under the inguinal ligament) [6] are used depending on the situation, need, indication and patient characteristics. The preferred vein is punctured either by using the landmark method (when external anatomical landmarks are used) or by using ultrasound (US). 
After the return of the venous blood from the targeted vessel a guidewire is passed through the needle, the needle is removed and the catheter is placed over the guidewire into the vein - Seldinger technique [9].

However, both techniques have some degree of risks for failure and complications. The landmark method can have a failure rate of $35 \%$ and an overall complication rate of $26 \%[7,8]$. Different modalities of ultrasound, among other efforts, have been used in an attempt to reduce the complication rate and increase the success rate of central venous catheterization $[4,10,11]$. Ultrasound can be used as static or dynamic. When static ultrasound is used the targeted vein is visualized on the US monitor and the skin is marked for the puncture site. The actual catheterization is performed blindly as with the landmark method. When dynamic ultrasound is used the whole procedure is guided by ultrasound control from skin puncture to guidewire placement [10]. The use of ultrasound enables visualization of the targeted venous vessel and its anatomical relationship with the surrounding structures and with the needle for catheterization. It allows detection of anatomical variations like vein and artery transposition and overlap. The use of ultrasound also, enables visualization of the correct position of the vein, its size, patency and eventual thrombosis, which is especially useful in patients with difficult anatomical characteristics (morbid obesity, cachexia, and scars on the skin at the puncture site). This allows the practitioner to choose the best skin puncture site [11].

Recommendations on the use of ultrasound for central venous catheterization have been made by many medical societies and government agencies like the Agency for Healthcare Research and Quality, the National Institute for Health and Clinical Excellence in the UK, the American Society of Echocardiography and the Society of Cardiovascular Anesthesiologists [10,12]. Despite these recommendations, the use of ultrasound for central venous catheterization remains low [13]. We have been using the ultrasound guided method in our intensive care unit for two years now.

The purpose of this study was to compare the success rate between ultrasound guided and landmark based central venous catheterization. In addition, the study included an analysis of the average number of attempts, average time to the return of blood, and the occurrence of mechanical complications (arterial puncture, pneumothorax and hematoma formation).

\section{MATERIAL AND METHODS}

This was a prospective study done during the period of 2015 and 2016 in the general intensive care unit at the Acibadem, Sistina Clinical Hospital in Skopje. After the approval by the ethical board at our hospital, a patient consent was obtained. Four hundred adult (18-70 years old) patients, with an indication for central venous catheterization were enrolled for the study. Patients were randomly (computer generated randomization) divided into two groups, group $\mathrm{A}(\mathrm{n}=200)$ included patients where for the CVC placement the ultrasound method was used and group $B(n=200)$ included patients who underwent CVC insertion with the landmark technique. For both groups of patients, the internal jugular, subclavian and femoral veins were used to get access to the central venous circulation. The placement of the CVC for each group was done by the same experienced team and under sterile technique (sterile cap, mask and gown).

The success rate, time to venous blood return, and mechanical complications were recorded for both groups.

A maximum of three attempts were allowed at the catheter site. An unsuccessful attempt was declared when after skin puncture, needle advancement and needle withdrawal there wasn't a return of venous blood from the targeted vein. After three unsuccessful attempts the procedure was terminated at the given site and declared unsuccessful. Time was measured from skin puncture to return of venous blood. Mechanical complications like arterial puncture, pneumothorax and hematoma were recorded. A pulsatile flow of bright red blood from the needle was a sign of arterial puncture. In such cases the needle was withdrawn from the skin and manual pressure was applied until hemostasis was achieved. Hematoma formation on the skin access site bigger than $1 \mathrm{~cm}$ in diameter was recorded. A radiographic examination of the lungs was made 6 hours after the procedure to check the catheter's position and check for pneumothorax.

All patients with subcutaneous emphysema, undergoing radiation therapy, skin inflammation at the insertion site, fractured clavicle, cardiac arrest, urgent patients, and patients with raised intracranial pressure were excluded.

\section{LANDMARK TECHNIQUE}

For the landmark method, the site for catheterization was chosen by the doctor doing the procedure depending on patient characteristics, anatomical landmarks, indication for catheteriza- 
tion, and his/hers experience. The first choice for landmark based central venous catheterization in our institution are the subclavian and jugular veins, while femoral vein is the second choice [14-16].

Anatomical landmarks for internal jugular vein catheterization were the medial border of the sternocleidomastoid muscle and the pulsations of the carotid artery. Subclavian vein was catheterized 1 centimeter below the junction of the medial and the lateral two thirds of the clavicle bone, and the femoral vein was catheterized two centimeters below the inguinal ligament and 1 centimeter medial of the palpable pulsations of the femoral artery [6].

For the jugular and subclavian vein catheterization the patients were placed in Trendelenburg position of 15 degrees and for femoral vein catheterization patients were placed in a horizontal position. The skin at the entry site was disinfected with $2 \%$ solution of chlorhexidine or $1 \%$ solution of betadine and was covered with sterile drape. The catheterization needle attached to a $5 \mathrm{ml}$ syringe with $2 \mathrm{ml}$ physiological solution was slowly advanced to the expected position of the targeted vein with continuous aspiration applied with the syringe clip. After the return of the venous blood in the syringe the needle guide was inserted and the procedure was finished according to the Seldinger's technique [9].

\section{US METHOD}

The jugular vein was the first choice for ultrasound guided central venous catheterization and the subclavian and femoral veins were the second choice [10]. An ultrasound exam was done before the procedure to determine the vein's position, its caliber and patency [17].

For the jugular vein catheterization, the ultrasound probe was applied on the lateral aspect of the neck. For the subclavian vein the probe was placed on the anterolateral aspect of the thorax 1 centimeter below the clavicle and for the femoral vein on the anterolateral aspect of the femoral region 2 centimeters below the inguinal ligament $[6,12]$. A non-compressible vein (thrombosis) or a vein diameter below $0.5 \mathrm{~cm}$ was an indication to use the same vein at the contralateral side or to use a different central vein for catheterization.

Patient preparation and positioning was the same as for patients in the landmark group.

For the ultrasound guided catheterization, an ultrasound machine General Electric e-Logic and a linear transducer 5 to $10 \mathrm{MHz}$ was used. Asepsis was achieved with sterile gel and sterile cover for the probe, Figure 1. Figure 2 and Figure 3 show

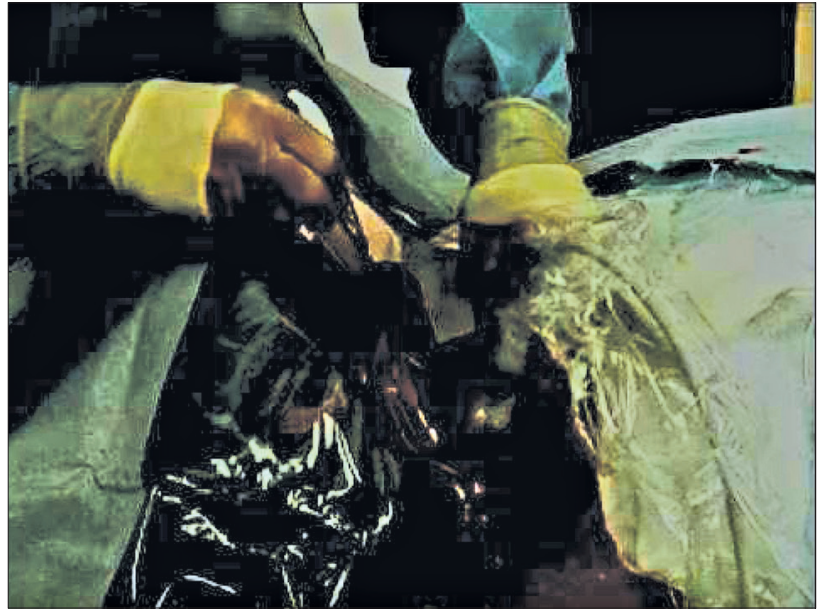

Figure 1. Ultrasound guided catheterization of the jugular vein with a short axis out-of-plane approach

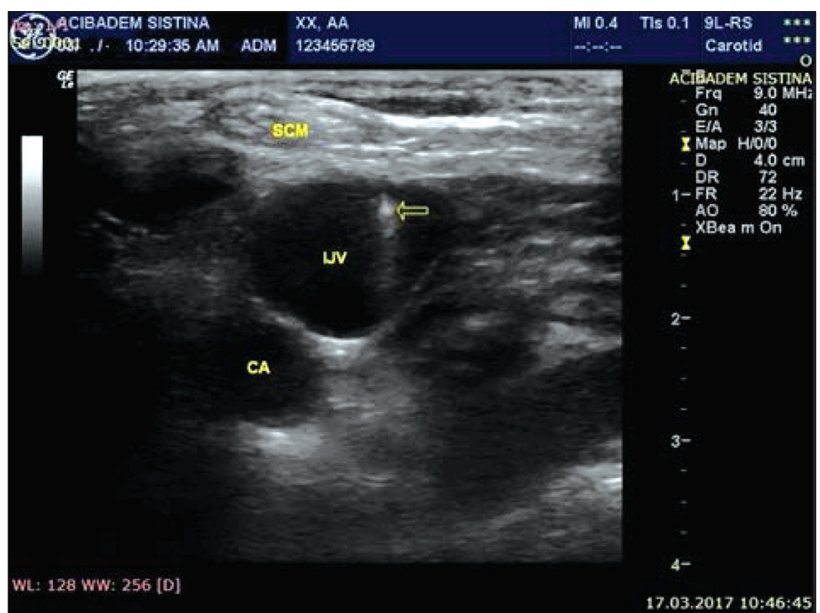

Figure 2. Short axis out-of-plane view of the jugular vein and the needle; the arrow is pointing at the needle seen as a hyperechoic dot on the ultrasound screen inside the lumen of the jugular vein; SCM-sternocleidomastoid muscle; IJV-Internal Jugular Vein; CA-carotid artery.

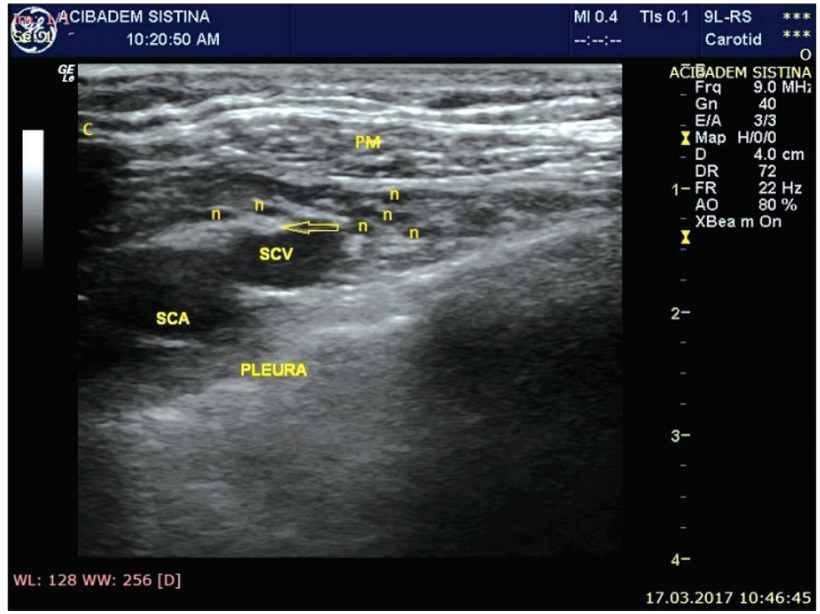

Figure 3. Short axis out-of-plane view of the subclavian vein and the needle Significant anatomic structures are marked: PM-pectoralis muscle, $n$-branches of plexus brachialis, C-clavicle, pleura, SCA-subclavian vein, SCA-subclavian artery, the arrow shows the needle before entering the blood vessel. 
the monitor image of the short axis out of plane view of the targeted vessel and the needle.

The ultrasound probe was applied in a 90-degree angle to the long axis of the targeted vessel and the needle for catheterization was inserted at the middle of the long axis of the probe to achieve a short axis out of plane approach [10]. With this approach the needle is shown as a hyperechoic dot on the US-monitor while the venous and arterial vessels are shown as hypoechoic oval and circular structures with well-defined borders. The vein is centered into the middle of the screen with slight movement of the probe and the needle was carefully advanced under ultrasound guidance until the anterior wall is punctured and venous blood is aspirated in the syringe connected to it. After documenting the return of the venous blood the Seldinger's technique for catheterization was used.

\section{RESULTS}

The study included 400 patients divided into two groups. The average age of the patients in the ultrasound group was 59.3 years and the average age of the patients in the landmark group was 59.2 years. The statistical difference between the groups for the average age is not significant. (Table 1) Male and female patients were equally represented in both groups. Both groups were homogenous regarding gender and age.

In the ultrasound group the jugular vein was catheterized in $41 \%$ of patients, the subclavian vein in $35.5 \%$ and the femoral vein in $23.5 \%$ of the patients.

The most commonly accessed vein in the landmark group was the subclavian vein in $45.5 \%$ of patients. The jugular vein was catheterized in $43 \%$, while the femoral vein was accessed in $11.5 \%$ of patients.

The difference between the groups for vein representation is statistically significant for the subclavian and femoral vein $\mathrm{p}<0.05(\mathrm{p}=0.0416$, and $\mathrm{p}=0.0016$ ) (Table 2).

In the ultrasound group 196/200 (98\%) of patients were successfully catheterized with the ultrasound guided catheterization while the landmark method was successful in 181/200 (90.5\%) of patients. The difference test was statistically significant for $\mathrm{p}<0.05(\mathrm{p}=0.0013)$.

In the ultrasound group the success on first attempt was $77 \%$ which was a significant increase from $60.5 \%$ achieved in the landmark group $\mathrm{p}<0.05(\mathrm{p}=0.0032)$.
The average number of attempts for successful catheterization in the ultrasound group was 1.25 (standard deviation $=0.511$ ), and in the landmark group it was 1.52 (Standard deviation=0.810). There was a statistically significant difference in the average number of attempts between groups for $\mathrm{p}<0.05$ (t-test $=4.009, \mathrm{p}=0.000074$ ).

On the average 13.6 seconds (standard deviation=11.6) were needed from skin puncture to blood return in the ultrasound group. The time was significantly increased in the landmark group 20.1 (standard deviation=20.3) due to the increased number of attempts and increased complication rate $(\mathrm{t}=3.85, \mathrm{p}=0.000139)$ (Table 3$)$.

\section{DISCUSSION}

Central venous catheterization is commonly performed in the intensive care unit. According to the study on prevalence of infection in the European intensive care units, $78 \%$ of patients have a central venous access device [18]. Central venous catheters are placed for fluid and medication administration, pacing, hemodialysis and for hemodynamic monitoring [19].

Traditionally for the landmark method, visible and palpable external landmarks with known relation with the targeted vessel are used to determine the puncture site on the skin [6]. This method is associated with complications that result in increased morbidity, longer hospital stay, increased expenses and mortality [4]. Nine percent of patients have abnormal central venous anatomy that makes central venous catheterization difficult and increase the risk of failure and complications [20]. The percent of failure with the landmark method can be as high as 35\% [8]. Complications are usually divided to early which occur during the catheterization and are mostly mechanical and late mostly infective and thrombotic in nature. The frequency of mechanical complications range between $5 \%$ and $19 \%$ [7]. Most common complication during jugular and femoral vein catheterization is arterial puncture. Pneumothorax is the most common complication during subclavian vein catheterization [4].

The use of direct ultrasound for central venous catheterization enables direct visualization of the targeted vein and surrounding structures before and during the catheterization. Studies show increased success and reduced complication rate with the use of direct ultrasound [17, $19,21]$. Some studies report that two dimensional ultrasound offers minimal advantage in safety 
Table 1. Average patient's age and side of the catheterization.

\begin{tabular}{|c|c|c|c|c|}
\hline & $\begin{array}{c}\text { Group B } \\
\text { Ultrasound } \\
(\mathrm{n}=200)\end{array}$ & $\begin{array}{c}\text { Group A } \\
\text { Control group } \\
(\mathrm{n}=200)\end{array}$ & $\mathrm{t}$ - value & $p$ value \\
\hline $\begin{array}{l}\text { Age } \\
(\mathbf{M} / \pm \text { SD })\end{array}$ & $59.3 \pm 12.42767$ & $59.2 \pm 12.83163$ & -0.06729 & 0.94638 \\
\hline $\begin{array}{l}\begin{array}{l}\text { Right side } \\
\text { (Number, \%) }\end{array} \\
\end{array}$ & $136 / 68 \%$ & $168 / 84 \%$ & \multirow{2}{*}{\multicolumn{2}{|c|}{$\mathrm{p}=0.0002$}} \\
\hline $\begin{array}{l}\text { Left side } \\
\text { (Number, \%) }\end{array}$ & $64 / 32 \%$ & $32 / 16 \%$ & & \\
\hline
\end{tabular}

Table 2. Vein representation in both groups

\begin{tabular}{|l|c|c|c|c|}
\hline \multirow{2}{*}{ Central vein } & \multicolumn{2}{|c|}{ Control } & \multicolumn{2}{c|}{ Ultrasound } \\
\cline { 2 - 5 } & Count & Percent (\%) & Count & Percent (\%) \\
\hline Jugular vein & 86 & 43.0 & 82 & 41 \\
\hline Subclavian vein & 91 & 45.5 & 71 & 35.5 \\
\hline Femoral vein & 23 & 11.5 & 47 & 23.5 \\
\hline overall & 200 & 100 & 200 & 100 \\
\hline
\end{tabular}

Table 3. Results of the punctures and complications in the study groups

\begin{tabular}{|l|c|c|c|}
\hline & $\begin{array}{c}\text { Group B } \\
\text { Ultrasound-Guided } \\
\text { (n=200) }\end{array}$ & $\begin{array}{c}\text { Group A } \\
\text { Landmark } \\
\text { (n=200) }\end{array}$ & p value \\
\hline $\begin{array}{l}\text { Success } \\
\text { Number / percent }\end{array}$ & $196 / 98 \%$ & $181 / 90.5 \%$ & 0.0013 \\
\hline $\begin{array}{l}\text { First attempt success } \\
\text { Number / percent }\end{array}$ & $154 / 77 \%$ & $121 / 60.5 \%$ & 0.0032 \\
\hline $\begin{array}{l}\text { Average number of attempts } \\
\text { (M/ISD) }\end{array}$ & $1.25 \pm 0.511$ & $1.52 \pm 0.810$ & $\begin{array}{c}\mathrm{t}=4.009 \\
\mathrm{p}=0.000074\end{array}$ \\
\hline $\begin{array}{l}\text { Average time } \\
\text { (M/ISD) }\end{array}$ & $13.6 \pm 11.6$ & $20.1 \pm 20.3$ & $\begin{array}{c}\mathrm{t}=3.85 \\
\mathrm{p}=0.000139\end{array}$ \\
\hline $\begin{array}{l}\text { Arterial puncture } \\
\text { Number / percent }\end{array}$ & $2 / 1 \%$ & $16 / 8 \%$ & $\mathrm{p}=0.0007$ \\
\hline $\begin{array}{l}\text { Pneumothorax } \\
\text { Number / percent }\end{array}$ & $0 / 0 \%$ & $7 / 3.955 \%$ & $\mathrm{p}=0.0259$ \\
\hline $\begin{array}{l}\text { Hematoma } \\
\text { Number / percent }\end{array}$ & $8 / 4 \%$ & $20 / 10 \%$ & $\mathrm{p}=0.018694$ \\
\hline
\end{tabular}

and quality during central venous catheterization of the subclavian vein (lower percent of arterial puncture and hematoma) and femoral vein (higher first pass success) [11]. The results of our study show that the ultrasound guided method is superior for central venous catheterization in intensive care patients compared to the landmark method.

The overall success with the landmark method was $90.5 \%$ which is in concordance with other reports where the overall success ranges between $85 \%$ and $100 \%[8,17,19,21,22]$. In our study, in $60.5 \%$ of the patients the catheterization was achieved in the first attempt. The incidence of arterial puncture with the landmark method was $8 \%$, while the incidence of hematoma formation and pneumothorax was $16 \%$ and $3.955 \%$ respectively. The incidence of these complications in the literature ranges between $10.6 \%-13 \%$ for arterial puncture $[19,23,24]$, hematoma formation $4 \%$ $8.4 \%[19,23]$ and pneumothorax 1\%-6.6\% [2527]. The higher rate of hematoma formation in our study appears as a result of the lower threshold of hematoma reporting of $1 \mathrm{~cm}$ in diameter.

The use of dynamic ultrasound resulted in higher overall success, the higher first pass success, shorter average time to the return of blood, the lower average number of attempts and the lower percent of mechanical complications, arterial puncture, pneumothorax and hematoma. These results correspond with other reports on the effect of dynamic ultrasound on the central venous catheterization $[10,17,19,21,28-30]$. The study by Karakitsos et al. (19) reports an overall success of $100 \%$ using ultrasound and $94.5 \%$ with the landmark technique. Fragou et al. [17] also achieved a success of $100 \%$ in the ultrasound group whereas 
the success in the landmark group was $87.5 \%$. Prabhu et al. [19] got a success rate of ultrasound catheterization of $98.2 \%$ compared to $89.1 \%$ of the landmark group. Regarding the complications, the study by Karakitsos [19] reports an arterial puncture of $1.1 \%$, hematoma of $0.4 \%$ and pneumothorax of $0 \%$ compared to $10.6 \%, 8.4 \%$ and $2.4 \%$ respectively, with the landmark technique. Neither arterial puncture nor pneumothorax were recorded in the ultrasound group in the study by Fragou et al. [17] as in our study.

All doctors in the study had a similar experience with the ultrasound method so a conclusion regarding the influence of experience on the success and complication rate during this procedure could not be made. The short axis out of plane approach was used in all catheterizations. During this approach the needle tip is not always seen so there is a greater risk of damage of deeper structures $(10,31)$. Even so, no pneumothorax was seen in our patients.

\section{CONCLUSION}

Ultrasound guidance during the central venous catheterization in intensive care patients increases overall, and the first pass success compared to the landmark method. At the same time the average time for return of the blood and the average number of attempts, as well as the arterial puncture, pneumothorax and hematoma formation are significantly reduced.

\section{Competing interests}

The authors declare that they have no competing interests.

\section{REFERENCES}

1. Emerman CL, Bellon M, Lukens TW, May TE, Effron D. A prospective study of femoral versus subclavian vein catheterization during cardiac arres. Annals of emergency medicine. 1990;19(1):26-30.

2. Joffe A, Anton, Lequier L, Vandermeer, Tjosvold L, Larsen B, et al. Nutritional support for critically ill children. The Cochrane Library. 2009.

3. Rajaram SS, Nayan DK, Ankur K, Mithil G, Susan CK, Brampton W, et al. Pulmonary artery catheters for adult patients in intensive care. Cochrane Database Syst Rev. 2013; 2.
4. McGee DC, Gould MK. Preventing complications of central venous catheterization. New England Journal of Medicine. 2003; 348(12):1123-1133.

5. Daily PO, Griepp B, Shumway E. Percutaneous internal jugular vein cannulation. Archives of surgery. 1970;101(4):534-536.

6. Bannon MP, Heller F, Rivera M. Anatomic considerations for central venous cannulation. Risk Manag Healthc Policy. 2011;4:27-39.

7. Merrer J, De Jonghe B, Golliot F, Lefrant JY, Raffy B, Barre, et al. Complications of femoral and subclavian venous catheterization in critically ill patients: a randomized controlled trial. Jama. 2001; 286(6):700-707.

8. Sznajder JL, Zveibil FR, Bitterman H, Weiner P, Bursztein SI. Central vein catheterization: failure and complication rates by three percutaneous approaches. Archives of Internal Medicine. 1986; 146(2):259-261.

9. Seldinger I. Catheter replacement of the needle in percutaneous arteriography: a new technique. Acta Radiologica. 1953 May 1; 39(5):368-376.

10. Troianos CA, Hartman GS, Glas KE, Skubas NJ, Eberhardt RT, Walker JD, et al. Guidelines for performing ultrasound guided vascular cannulation: recommendations of the American Society of Echocardiography and the Society of Cardiovascular Anesthesiologists. Journal of the American Society of Echocardiography. 2011; 24(12):1291-1318.

11. Brass P, Hellmich, Kolodziej L, Schick G, Smith F. Ultrasound guidance versus anatomical landmarks for subclavian or femoral vein catheterization. Cochrane Database Syst Rev. $2015 ;(1)$.

12. Guidance on the use of ultrasound locating devices for placing central venous catheters.. Ntioanal INstitute of Health Care and Clinnical Excellence; September 2002.

13. Maizel J, Bastide MA, Richecoeur J, Frenoy E, Lemaire C, Sauneuf B, et al. Practice of ultrasound-guided central venous catheter technique by the French intensivists: a survey from the BoReal study group. Annals of Intensive Care. 2016;6(1):76.

14. Ameh V, Jones S. Central venous catheterisation: internal jugular or subclavian approach? Emergency Medicine Journal. 2007;24(9):662-663. 
15. Torgay A, Pirat A, Candan S, Zeyneloglu P, Arslan G, Haberal M. Internal jugular versus subclavian vein catheterization for central venous catheterization in orthotopic liver transplantation. InTransplantation proceedings. 2005; Vol. 37, No. 7, 3171-3173. Elsevier.

16. Timsit JF. What is the best site for central venous catheter insertion in critically ill patients? Critical Care. 2003;7(6):1.

17. Fragou M, Gravvanis A, Dimitriou V, Kouraklis G, Karabinis A, Saranteas T, et al. Real-time ultrasound-guided subclavian vein cannulation versus the landmark method in critical care patients: a prospective randomized study. Critcal Care Medicine. 2011; 39(7):1607-1612.

18. Vincent JL, Bihari J, Suter M, Bruining A, White J, Nicolas-Chanoin $\mathrm{MH}$, et al. The prevalence of nosocomial infection in intensive care units in Europe: results of the European Prevalence of Infection in Intensive Care (EPIC) Study. Jama. 1995;274(8):639-644.

19. Karakitsos D, Nikolaos L, De Groot E, Patrinakos AP, Gregorios K, John P, et al. Real-time ultrasound-guided catheterisation of the internal jugular vein: a prospective comparison with the landmark technique in critical care patients. Critical Care. 2006; 17;10(6):R162.

20. Denys BG, Uretsky BF, Reddy PS. Ultrasound assisted cannulation of the internal jugular vein: a prospective comparison to the external landmark-guided technique. Circulation. 1993;87(5):1557-1562.

21. Prabhu V, Juneja, Palepu GB, Sathyanarayanan M, Subhramanyam, Gandhe S. Ultrasound-guided femoral dialysis access placement: a single-center randomized trial. Clinical Journal of the American Society of Nephrology. 2010; 5(2):235-239.

22. Lefrant JY, Muller L, De La Coussaye JE, Prudhomme M, Ripart J, Gouzes C, et al. Risk factors of failure and immediate complication of subclavian vein catheterization in critically ill patients. Intensive care medicine. 2002;28(8):1036-1041.
23. Matthew MJ, Husain FA, Piesman M, Mullenix PS, Steele SR, Andersen CA, et al. Is routine ultrasound guidance for central line placement beneficial? A prospective analysis. Current surgery. 2004;61(1):71-74.

24. Mansfild PF, Hohn CD, Fornage DB, Gregurich MA, Ota M. Complications and failures of subclavian-vein catheterization. New England Journal of Medicine. 1994; 331(26):1735-1738.

25. Cronen MC, Cronen PW, Arino P, Ellis K. Delayed pneumothorax after subclavian vein catheterization and positive pressure ventilation. British journal of anaesthesia. 1991;67(4):480-482.

26. Takeyama H, Taniguchi M, Sawai H, Funahashi H, Akamo Y, Suzuki S, et al. Limiting vein puncture to three needle passes in subclavian vein catheterization by the infraclavicular approach. Surgery today. 2006;36(9):779-782.

27. Kilbourne MJ, Bochicchio GV, Scalea T, Xiao Y. Avoiding common technical errors in subclavian central venous catheter placement. Journal of the American College of Surgeons. 2009; 208(1):104-109.

28. Miller AH, Brett RA, Mills TJ, Woody R, Longmoor CE, Foster B. Ultrasound guidance versus the landmark technique for the placement of central venous catheters in the emergency department. Academic Emergency Medicine. 2002;9(8):800-805.

29. Shah A, Smith A, Panchatsharam S. Ultrasound-guided subclavian venous catheterisation-is this the way forward? A narrative review. International journal of clinical practice. 2013; 67(8):726-732.

30. Troianos CA, Jobes DR, Ellison N. Ultrasound-guided cannulation of the internal jugular vein. A prospective, randomized study. Anesthesia \& Analgesia. 1991; 72(6):823-826.

31. Blaivas M AS. Blaivas M, Adhikari S. An unseen danger: frequency of posterior vessel wall penetration by needels during atemts to place central catheters during ultrasound guidence. Critical Care Medicine. 2009;37:2345-2349. 


\section{СПОРЕДБЕНА АНАЛИЗА НА УЛТРАЗВУЧНО ВОДЕНА ЦЕНТРАЛНА} ВЕНСКА КАТЕТЕРИЗАЦИЈА НАСПРОТИ СЛЕПА КАТЕТЕРИЗАЦИЈА

Дарко Саздов ${ }^{1}$, Марија Јовановски Срцева ${ }^{2}$, Зорка Николова Тодорова ${ }^{3}$

${ }^{1}$ Клиничка болница Аџибадем-Систина, Скопје, Оддел за Интензивно Лекување

${ }^{2}$ Универзитетска Клиника за Трауматологија Ортопедија Анестезија Реанимација и Интензивно Лекување, Скопје

${ }^{3}$ Европска Очна Болница, Скопје

\section{Резиме}

\section{Вовед:}

Централна венска катетеризација секојдневно се спроведува со слепа или ултразвучно водена метода. Целта е да се споредат успехот, просечното време до добивање крв, просечниот број обиди, и механичките компликации при катетеризација меѓу овие две методи.

\section{Материјал и Методи:}

Во проспективна студија беа вклучени 400 возрасни пациенти од единицата за интензивно лекување (ЕИЛ) во Клиничката болница Аџибадем Систина, Скопје. Пациентите во испитуваната група беа катетеризирани со ултразвучно водена метода. Кај пациентите во контролната група централен венски катетер беше поставен со помош на надворешни обележја т.н.слепа катетеризација. Кај двете групи пациенти беа пунктирани внатрешната југуларна, потклучната и феморалната вена и следени, успешноста, времето од боцкање на кожата до добивање крв, бројот на убоди до успешна катетеризација и појава на компликации во моментот на катетеризација.

\section{Резултати:}

Катетеризацијата со помош на слепата метода беше успешна кај 90,5\% од пациентите, и тоа кај 60,5\% при првиот обид, а успешноста со ултравучно водената метода беше $98 \%$ и тоа $77 \%$ при првиот обид. Компликации во контролната група се среќаваат кај 14,5\% пациенти, наспроти 4\% во испитуваната група што претставува статистички сигнификантна разлика за $\mathrm{p}<0.05$ ( $\mathrm{p}=0.0008)$

\section{Заклучок:}

Ултразвучно водената метода за пристап до централната венска циркулација во интензивна нега, ја зголемува успешноста, го намалува бројот на обиди и потребното време за катетеризација како и механичките компликации асоцирани со оваа постапка.

Клучни зборови: Слепа катетеризација, ултразвук, централна вена 